\title{
Development Of Pop-Up Book Learning Media On Earth Oil Materials
}

\author{
Yoshiya Hazumi \\ National Institute for Materials Science (NIMS), Japan and The University of Tokyo, Japan \\ Email:yoshiya1@gmail.com
}

\begin{abstract}
The aimed of this study was to develop learning media called pop-up book of petroleum. The method was research and development (Research and Development) with the ADDIE model of which consisted of 5 steps: Analysis, Design, Development, Implementation and Evaluation. The data were collected using questionnaire for media validation. The results showed that pop-up book was found to be $92.67 \%$ valid (very decent), meant that the developed pop-up book could be study in terms of its effectiveness in learning.
\end{abstract}

Keywords: pop-up book, petroleum, ADDIE model,

\section{A. INTRODUCTION}

Chemistry is one of the lessons that has a lot of applications in everyday life. Many natural phenomena that occur in everyday life can be solved by chemistry, so that this lesson has been introduced since elementary school (SD) to university (PT). Many opinions state that learning chemistry is a difficult and abstract lesson to accept, so students' interest in chemistry tends to decrease. Fibriani et al. (2014), chemistry is a difficult subject, many chemical concepts are abstract, the amount of material that must be understood and mastered makes students become bored and not interested in learning chemistry. The same thing was also stated by Sudjana (2015) that the process of teaching and learning chemistry is still conveyed to the extent of the product. Students only hear and record things that are considered important, and tend to be required to memorize formulas, theories and laws only. This condition makes it easy for students to feel bored or bored and do not like chemistry lessons which ultimately results in a less than optimal understanding of the material presented. Teaching is the main task of an educator, so it is required to always be creative in creating ideas in designing new learning systems that are able to make students achieve their learning goals with full meaning. A chemistry teacher needs to know the kinds of learning media that can be used in teaching, because with the learning media it is expected that students will be happier, more excited, interested and have a positive attitude towards learning chemistry (Epinur et al., 2014).

Fibriani et al. (2014) explains that professional teachers not only need to prepare course material, but are also required to be creative in using and developing learning media. Learning media will facilitate interaction between teachers and students so that learning activities will be more effective and efficient. Learning media created must also be able to arouse the curiosity of students. If only listening to verbal information from the teacher alone, students will not understand the lesson nicely. Learning will be more meaningful if students are involved in seeing, touching or 
experiencing themselves through the media. Learning media are components of learning resources or physical vehicles that contain instructional material that can stimulate students to learn. The media has a clear function which is to clarify, facilitate and make interesting material that will be delivered by the teacher to students so that it can motivate their learning and streamline the learning process (Mawarni et al., 2015). One of the learning media that can be used in learning is the pop-up book media. Pop-up is an interesting form of paper art that forms a three-dimensional structure when opened and a two-dimensional structure when closed (Lizuka et al., 2011; Mahadzir and Li., 2013). Pop-ups are more than just producing 3D shapes, but using movements that can make the reader feel happy (Ruiz et al., 2015). Pop-up book learning media are considered to have a special attraction for students because they are able to present visualizations in forms that are made by folding, moving and appearing so as to provide surprises and admiration for students when opening each page (Khoiraton et al., 2014). The advantage of pop-up book media is that it provides special experience for students because it involves students such as sliding, opening, and folding the pop-up book. This will make its own impression to the reader so that it will be easier to enter into memory when using this media (Setyawan et al., 2014).

Petroleum is a material taught in high school in class 2 semester 1 . The application is widely available in daily life (Jannah et al., 2013), such as asphalt, cooking gas, gasoline, diesel fuel, candles and others. Petroleum material requires students' perseverance to read and understand enough to learn it (Tyasning et al., 2012; Astrissi et al., 2014). Petroleum is a material that is obtained by understanding a lot of reading, so we need an innovation so that students remain active during learning. One innovation that can be done is learning media (Marfuatun et al., 2012). According to Epinur et al. (2014), learning will be more easily understood in the presence of media. The use of pop-up book media on petroleum material can help students' understanding of material related to petroleum, because this media is able to present a concrete impression in the learning process. Students seem to be able to see directly the layers of the earth where it was formed and the deposition of oil and gas. Multilevel distillation tubes can be presented in the learning process so that students do not have to go to the petroleum refining center.

\section{B. METHODOLOGY}

This study uses research and development methods used to produce certain products, and test the effectiveness of these products (Sugiono, 2010). The development model used is the ADDIE model, consisting of analysis, design, development, implementation and evaluation (Personal, 2011). The selection of research sites is based on the results of a case study in 2015 that the high school experienced problems in learning chemistry, so researchers wanted to follow up on the problem to find a solution. The product trial process was carried out on 7-9 November 2016. The sampling technique is done by random sampling, because all four classes have the same absorption. The instrument used in the form of a media 
validation questionnaire was given to 5 validators, consisting of 2 expert validators, and 3 chemistry teachers from several schools in Banda Aceh.

\section{RESULT AND DISCUSSION}

This research aims to develop a learning media for petroleum material pop-ups with the ADDIE model which consists of five stages, namely analysis, design, development, implementation and evaluation. ADDIE model was chosen because this model has clear, systematic, effective and efficient steps stated that the ADDIE model has flexible guidelines that help instructional designers in developing effective media.

\section{Analysis}

The analysis phase, researchers analyzed three aspects, namely the learning process, subject matter and learning media that are often used. Based on observations of the learning process in several classes, information is obtained that the learning process still uses teacher-centered lecture methods, students only listen and are not actively involved during learning. The results of the researchers' interview with one of the chemistry teachers and several students at the school, petroleum material is usually taught by the lecture method or group discussion, while the learning media used in the form of two-dimensional media such as LKPD and textbooks. Limited computer space causes multimedia media to also never be used. Pop-up learning media itself has never been used at the school. The results of the needs analysis in terms of these three aspects become a problem for students. There were supposed to be several alternative media used in chemistry learning, so it was decided to develop pop-up book learning media on petroleum material. Pop-up book media was chosen because this learning media has never been applied in the high school, so it is hoped that it can become a new variation in the learning process.

\section{Design}

The design stage, the learning media pop-up book is designed in such a way that the developed media can attract students to study petroleum material so that it will produce a fun learning process. At this stage, several components are needed in making learning media. The components, tools and materials needed in designing pop-up book learning media are laptops / computers, petroleum material books, syllabi, images related to petroleum, 260 gram paper, scissors, ruler, cutter, glue, and pencil.

\section{Development}

The development phase is carried out making media using components, tools and materials that have been described at the design stage. This is in accordance with Irwan et al. (2014), the development stage is the stage where all materials or components collected from both the analysis and design stages are collected into one and converted into a ready-to-use media. The printed products are then validated by a validator consisting of 2 expert lecturers and 3 chemistry teachers. The assessment 
process is carried out by providing learning media for pop-up books that are ready for review and a validation questionnaire accompanied by suggestions for improvements to the learning media for pop-up books. Table 1 shows some input from the validator towards learning media in pop-up books.

Table 1. Evaluation Results and Input by Experts

\begin{tabular}{|c|c|}
\hline NO & Input from validator \\
\hline 1 & Improvements to writing are still wrong. \\
\hline 2 & $\begin{array}{l}\text { The matter of training is not dominated by environmental pollution, there must be } \\
\text { special material about environmental pollution. }\end{array}$ \\
\hline 3 & $\begin{array}{l}\text { - Add structural formula information from the constituent compounds of } \\
\text { gasoline } \\
\text { - Media colors should be brightened to make it more attractive. } \\
\text { - Use thicker adhesive and paper to make the pop-up stand upright. }\end{array}$ \\
\hline 4 & Paper pages 9 and 10, you should use the same paper as the background. \\
\hline 5 & Pup book learning media is appropriate to be used without revision. \\
\hline
\end{tabular}

Based on suggestions from the validator, the learning media for the popup book was revised again. Improvement of the overall learning media of popup books, namely improvements in terms of color, based on the suggestions of the color validator in the learning media of pop-up books more enlightened to make students more interested. Some mistakes in typing, the sub-material gasoline added information on the structure of the compounds making up gasoline are isooktane and n-heptane. Page 10 paper repair used, where the paper used previously is orange paper, replaced with 260 gram paper so it is uniform with the rest of the pop-up book. The percentage of the results of the validation of each validator can be seen in Figure 1.

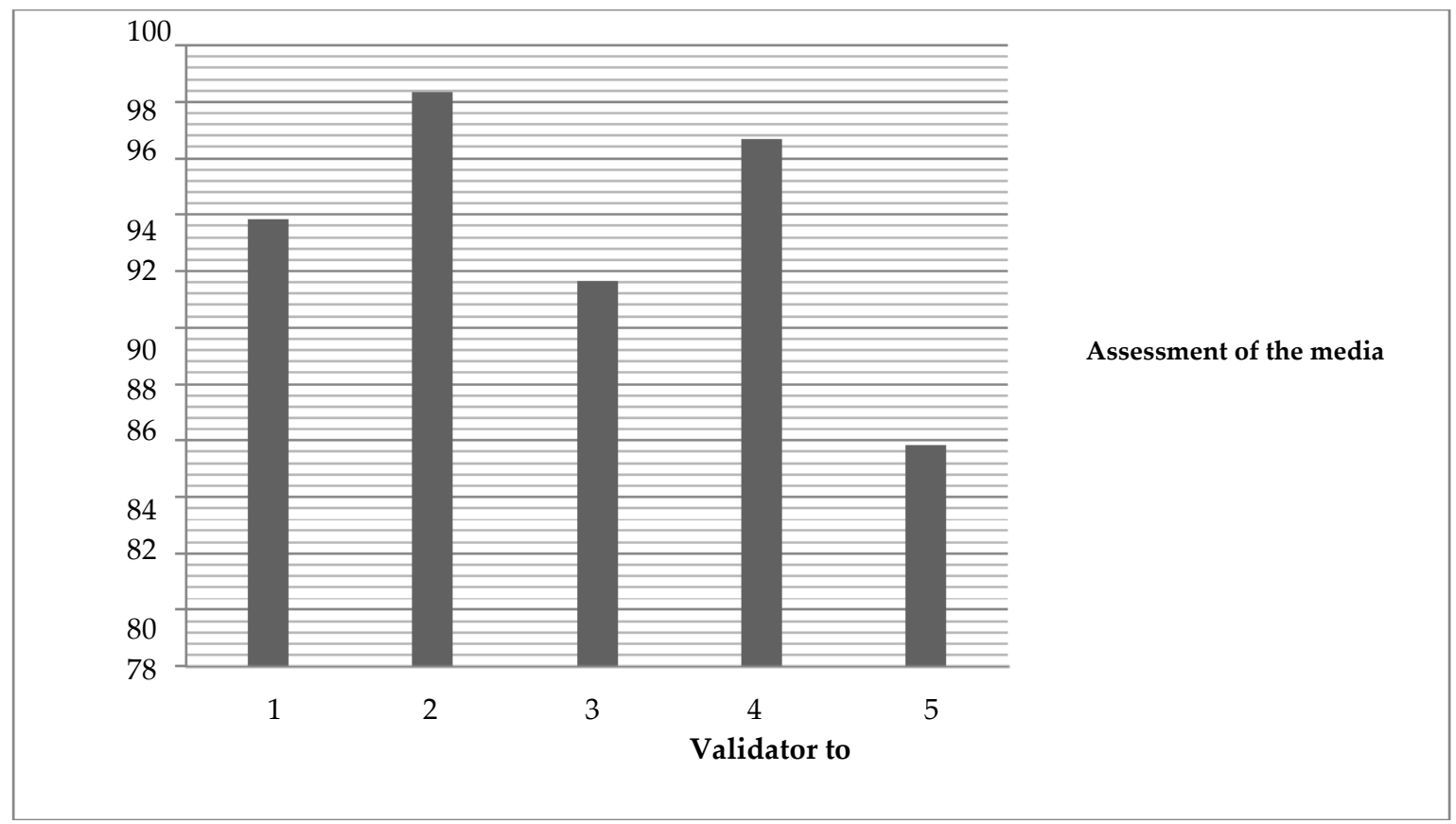




\section{Figure 1. Percentage of results of the validation of the learning media pop-up book by the validator}

The results of the validation of an average of 5 validators to the learning media pop-up book with ADDIE model of $92.67 \%$ with very decent qualifications. This is in accordance with Marhamah (2015), the pop-up media is validated by three expert validators with the results of the media validity obtained from the average validator results of $88 \%$ which are categorized very well. The technique of making pop-ups is basically the same as the technique of folding origami paper, the difference lies in the amount of paper used, wherein the pop-up uses more than one paper and most of it requires varying cuts (Winder et al., 2009). Making pop-ups is actually relatively easy if someone has the technique and knowledge of pop-up books. They just need to fold the appropriate paper and stick it. But for those who are not professional, it will be very difficult. First it is difficult to determine the mechanism of the pop-up and then it is difficult to determine the position of the pop-up so that when the book is closed a part of the pop-up can be hidden in it (Okamura and Igarashi, 2009).

\section{Implementation}

Implementation is a concrete step to apply the learning media that has been made. At this stage everything that has been developed is set so that it can be implemented to the target (Budiarta, 2013). In this research, the implementation phase is only limited to small-scale trials to get the responses of teachers and students to the media that have been developed. This is consistent with Sukmadinata's statement (2008: 174) that initial scale trials can be carried out in 1 to 3 schools while extensive trials are conducted in 5 to 15 schools. Teacher trials were conducted on November 7 and 8,2016 . Trials on teachers were conducted by showing the developed media for learning pop-up books and explaining how to apply them in accordance with the RPP that researchers have made. The purpose of the pilot test is to find out the teacher's response to the learning media pop-up book that has been developed.

\section{Evaluation}

Evaluation, this stage is the last stage of the development phase of ADDIE. After the implementation, it is known that the response of the teacher and students to the media for learning pop-up books of petroleum material that has been developed, is then evaluated if there are deficiencies in the use of real conditions. The results of the implementation of teachers and students obtained by learning media pop-up books in the very good category, so no evaluation or improvement is needed, because at the evaluation stage the thing done is product improvement based on the implementation of the developed media (Pawana et al., 2014). The results of this study are in accordance with Marhamah (2015), the design of pop-up book media using the ADDIE model has a validity rate of $88 \%$ and the average student response reaches 
$82 \%$, and has an effectiveness of $97 \%$ which means that the pop-up book media is very effectively used as a learning medium. Found that the chemistry pop-up book of atomic theory material is very good percentage of ideals of each aspect in a row that is 93.33, 95.08 and 89.00. Hawarya and Warso (2014), developed a biology learning pop-up module on pollution and environmental preservation materials for grade $X$ (ten) high school students, with the results of the study categorized both with assessment components in the form of content, language and picture, presentation, and graphics or feasibility. display.

\section{CONCLUSION}

Based on the results of research and development that has been done, it is concluded that the media for learning pop-up books of petroleum materials that have been developed through the ADDIE model, through the stages of analysis, design, development, implementation and evaluation with an average percentage of feasibility of 5 validators of 92,67 . This shows that the media for learning pop-up books on petroleum material is very suitable for use as a learning medium.

\section{REFERENCES}

1. Astrissi, D.O.S.A.G, Sukardjo, J.S \& Hastuti. B. (2014). The Effectiveness of the Teams Games Tournament (TGT) Learning Model Accompanied by Crossword Puzzles Against Learning Achievement in Petroleum Materials for Class X Students of SMA Negeri 3 Sukoharo in the 2012/2013 Academic Year. Journal of Chemical Education (JPK), 3 (2): 22-27.

2. Budiarta, W.I. (2013). Development of Addie Interactive Interactive Multimedia Model to Improve Student Motivation for History of Class X-1 Even Semester at Sman 1 Sukasada, Buleleng, Bali. Journal of Historical Education, Ganesha Singaraja University of Education, 2 (1): 1-12.

3. Dewi, K. T, Suastra. I. W. \& Pujani, N. M.(2013). Effects of Learning Models Analyze, Design, Develop, Implement, Evaluate (ADDIE) Against Critical Thinking Skills and Understanding Physics Concepts. e-Journal of Ganesha University's Graduate School of Education Science Study Program, 3 (1): 110.

4. Epinur, Syahri, W., \& Adriyani.(2014). Development of Chemistry Learning Media on Electrochemical Materials for Class XII of SMAN 8 Jambi City by Using Prezi Software. J. Ind. Soc. Integ. Chem, 6 (1): 13-22.

5. Fibriani, L., Damris, M. \& Risnita.(2014). Development of Interactive Learning Multimedia to Increase Motivation and Learning Outcomes of Students in High School Chemical Equilibrium Materials. Edu-Sains, 3 (1): 15.

6. Hawarya, Y \& Warso, A.W.D.(2014). Development of Biology Learning Popup Module on Pollution and Environmental Preservation Materials for High School Students in Class X. JUPEMASI-PBIO, 1 (1): 139-143. 
7. Irwan. F, I. W. Santyasa, I M. \& Tegeh.(2014). Development of Interactive Multimedia Based on Self Regulated Learning with ADDIE Model to Improve the Achievement of Learning Cultural Arts for Class VII Students of Mendoyo Public Middle School 3. E-Journal of Ganesha University Graduate School of Education Learning Program, 4: 1-10.

8. Jannah, R., Saputro, A.N.G \& Yamtinah, S.(2013). Application of Think Pair Share (TPS) Learning Model Accompanied by a Pocket Book to Increase Chemistry Learning Activities and Achievements in Class X Petroleum Materials in Gondangrejo State High School 2012/2013 Academic Year. Journal of Chemical Education (JPK), 2 (4): 19-23.

9. Khoiraton, A. Fianto, A.Y.A., \& Riqqoh, A.K.(2014). Sangiran Museum Popup Book Design as a Learning Media About Historical Heritage. Journal of Visual Communication Design, 2 (1): 1-8.

10. Khoirunnisa, O.R.(2015). Development of Chemistry Pop-up Book Atom Theory Material as a Independent Learning Source for Students in Class X. EJournal UNY, 4 (1): 1-8.

11. Lizuka, S., Endo, Y., Mitani, J., Kanamori, Y., \& Fukui, Y.(2011). An Interactive Design System for Pop-Up Cards With A Physical Simulation. Vis Comput, 27: 605-612.

12. Marfuatun, Marwati, S. \& Budiasih, K.S.(2012). Development of Learning Media Based on MX Program Director in Learning Topics of Core Chemistry and Radiochemistry. Educational Horizon, 2 (31) :: 256-266.

13. Marhamah (2015). Design and Effectiveness of Pop-up Book Learning Media with ADDIE Model in Geography Subjects for Volcanism Class VII in PKPU Middle School. Unpublished thesis: PPs Syiah Kuala University.

14. Mawarni, E., Mulyani, B \& Yamtinah, S.(2015). Application of Peer Tutoring Equipped with Macromedia Flash and Handout Animation to Increase Achievement Motivation and Learning Achievement of Students in Class XI Science 4 of SMAN 6 Surakarta in 2013/2014 Academic Year on Material Solubility and Results Solubility times. Journal of Chemical Education (JPK), 4 (1): 29-37.

15. Nadiyah, R.S. \& faaizah, S.(2015). The Development of Online Project Based Collaborative Learning using ADDIE Model. Procedia-Social and Behavioral Sciences, 195 (1): 1803-1812.

16. Mahadzir, N.N.N \& Li, F.P.(2013). The Use of Augmented Reality Pop-Up Book to Increase Motivation in English Language Learning For National Primary School. IOSR Journal of Research \& Method in Education, 1 (1): 2638.

17. Okamura, S \& Igarashi, T.(2009). An Interface for Assisting the Design and Production of Pop-Up Cards. Verlag Berlin Heidelberg, 1: 68-78.

18. Pawana, M. G., Suharsono. N., \& Kirna, I.M.(2014). Development of ProjectBased Interactive Multimedia with ADDIE Models on Web Programming Materials for Class X Even Semester Students at SMK Negeri 3 Singaraja. E- 
Journal of Ganesha University Graduate School of Education Learning Program, 4: 1-10.

19. Setyawan, D., Usada \& Mahfud, H.(2014). Application of Pop-Up Book Media to Improve Speaking Skills. Didaktika Dwija Indria Journal, 2 (11): 1-5.

20. Sudjana, D.(2015). Cation-Anion Cards as Learning Media Innovation in Chemistry Subjects in Senior High Schools. Widyaiswara Circle Journal, 2 (1): 21-37. 